\title{
Kompensasi, Situasi Kepemimpinan dan Iklim Kerja Organisasi
}

\author{
Thomas Nadeak \\ Buana Perjuangan University \\ Program of Accounting Science, Faculty of Bisnis and Sosial \\ Karawang, Jawa Barat, Indonesia \\ Email : misterichi@yahoo.com
}

\begin{abstract}
This research purposes are to explain and analyzing the Strength of Compensation Influence and Leadership Situation with the Organization Working Climate.This research is using quantitative with the description design using SPPS IBM Advance V21 software.The research method is used a survey method, with quantitative approach using qusioner as main instrument to collect data. The populations used in this sample are 68 out of 85 persons. As partial,there are significant positive influences of compensation to working organization climate and The Leadership Climate. Overall, there are positive compensation influence and leadership situation to working organization climate. On this research, researcher also suggest that the foundation have to focusing on teachers welfare and the leadership must better than one way leadership to be participative leadership to prevent the fast turnover of the teacher.
\end{abstract}

Keywords : Compensation, Leadership Situation and Working Organsization Climate

\begin{abstract}
ABSTRAK
Penelitian ini bertujuan menjelaskan dan menganalisis kekuatan pengaruh kompensasi dan situasi kepemimpinan dengan iklim kerja organisasi, penelitian ini merupakan penelitian kuantitatif dengan desain deskripsi dengan memakai software SPSS IBM Advance versi 21. Metode penelitian yang digunakan adalah survai, dengan pendekatan kuantitatif dengan menggunakan kusioner sebagai instrument utama untuk mengumpulkan data populasi yang dijadikan sampel sebanyak 68 orang dari 85 orang populasi. Secara parsial terdapat pengaruh positif signifikan kompensasi terhadap iklim kerja organisasi dan situasi kepemimpinan terhadap iklim kerja organisasi. Secara keseluruhan terdapat pengaruh bersama positif signifikan kompensasi dan situasi kepemimpinan terhadap iklim kerja organisasi. Didalam penelitian ini peneliti juga menyarankan bahwa perusahaan harus memperhatikan kesejahteraan guru dan kepemimpinan harus lebih baik dengan kepemimpinan satu arah menjadi kepemimpinan yang partisipatif agar keluar masuknya guru tidak sesering mungkin.
\end{abstract}

Kata Kunci : Kompensasi, Situasi Kepemimpinan dan Iklim Kerja Organisasi

\section{Pendahuluan}

SMK Yadika 11 adalah salah satu SMK swasta yang cukup di perhitungkan di Bekasi.

Sekolah ini mempunyai siswa sebanyak 1300 orang setiap tahunnya. Dalam teori-teori motivasi kerja kita perlu mengambil teori dari Abraham yang merumuskan salah satu teori kebutuhan yaitu bahwa kebutuhan didefinisikan sebagai suatu kesenjangan atau pertentangan yang dialami antara suatu kenyataan dengan dorongan yang ada dalam diri. Apabila pegawai kebutuhannya tidak terpenuhi maka pegawai tersebut akan menunjukkan 
perilaku kecewa. Oleh karena itu sekolah harus memiliki kemampuan untuk mempertahankan bahkan meningkatkan kualitas sumber daya manusia yang dimilikinya dengan harapan tercapainya tujuan perusahaan.

Ada banyak cara yang bisa dilakukan oleh perusahaan, salah satunya melalui kompensasi gaji. Pemberian kompensasi merupakan salah satu cara yang diharapkan dapat merangsang motivasi kerja karyawan dalam organisasi perusahaan. Kompensasi adalah segala sesuatu yang diterima oleh karyawan sebagai balas jasa atau upaya-upaya yang telah diberikan kepada organisasi perusahaan ( Hendri Tanjung, 2003 ).

Tujuan dari penelitian ini untuk mengetahui dan menganalisis hubungan Kompensasi,Situasi Kepemimpinan dengan Iklim Kerja pada unit Yadika 11. Hasil penelitian ini diharapkan dapat memberikan masukan bagi pihak manajemen Yayasan Abdi Karya dalam mengevaluasi dan mengambil kebijakan yang berkaitan dengan pemberian kompensasi sehingga masukan ini dapat membantu dalam proses pencapaian tujuan perusahaan.

\section{Metode Penelitian}

Dalam penelitian ini yang digunakan adalah penelitian metode survey dengan menggunakan kuesioner sebagai teknik pengumpulan data. Dari variabel tersebut selanjutnya di cari seberapa besar pengaruh variabel independen terhadap variabel dependen. Penelitian ini bertujuan untuk menguji dan menganalisis hubungan Kompensasi dan Situasi Kepemimpinan dengan Iklim Kerja Organisasi di Unit Yadika 11 Jatirangga.

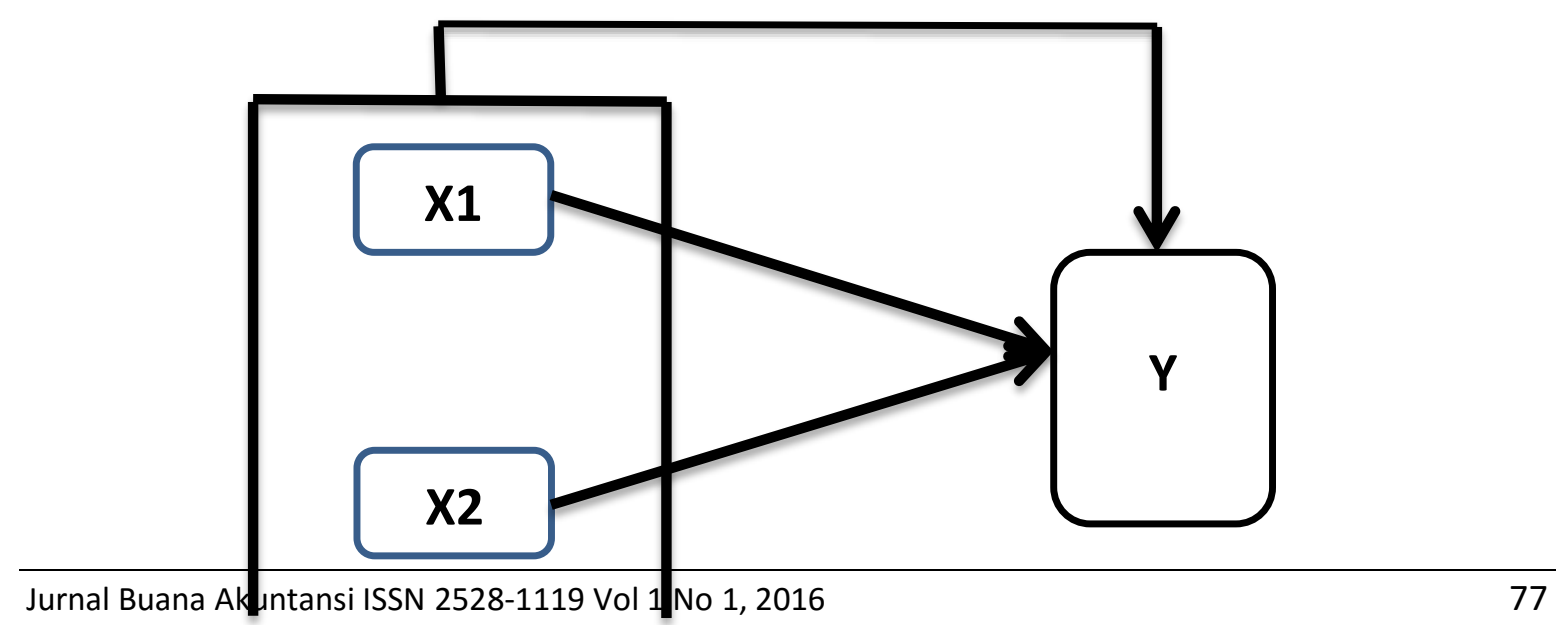


Gamber 3.1

Model Hubungan Variabel Bebas (X1,X2) dengan Variabel terikat (Y).

Keterangan :

$$
\begin{aligned}
& \text { X1 : Kompensasi } \\
& \text { X2 : Situasi Kepemimpinan } \\
& \text { Y : Iklim Kerja Organisasi }
\end{aligned}
$$

Pelakasanaan penelitian dilaksanakan di unit Yadika 11 Jatirangga. Penelitian ini dilakukan terhadap guru pada bulan Februari sampai dengan Mei 2015. Didalam penelitian ini yang menjadi objek adalah sumber daya manusia dengan pemusatan pada kompensasi, Situasi Kepemimpinan dan Iklim kerja Organisasi.

Adapun sampel yang saya buat adalah berjumlah 68 orang dari 85 populasi guru. Dalam melakukan pengumpulan data sebanyak 3 instrumen penulis lakukan yaitu tentang Kompensasi (X1), Situasi Kepemimpinan (X2) dan Iklim Kerja Organisasi (Y).

Tahap-tahap analisis data adalah :

1. Mendeskripsikan data untuk setiap variabel penelitian

2. Melakukan uji persyaratan analisis

3. Menguji Hipotesis

Uji persyaratan analisis diperlukan sebagai persyaratan sebelum melakukan uji hipotetis dengan korelasi maupun analisis regresi. Uji persyaratan tersebut meliputi uji Normalitas, Uji Homogenitas dan Uji Linearitas. Uji Normalitas menggunakan rumus Kolmogrov Smimov. Uji Homoginitas menggunakan uji beda varian, sedangkan uji Linearitas dengan uji alat regresi linear. Uji hipotesis pertama dilakukan dengan analisis korelasi sederhana (ry1), Uji signifikan korelasi 
sederhana melalui uji-t, koefisien determinasi $\left(r^{2} y 1\right)$, persamaan garis regresi linear dengan persamaan garis $\mathrm{Y}=\mathrm{a}+\mathrm{bx} 1$ disertai tabel dan makna persamaan tersebut.

Uji Hipotesis kedua dilakukan dengan analisis korelasi sederhana (ry2), uji signifikan korelasi sederhana melalui Uji-t, koefisien determinasi $\left(r^{2} y^{2}\right)$, persamaan garis regresi linear dengan persamaan garis $y=a+b x 2$ disertai tabel dan pengertian persamaan tersebut.

Uji Hipotetis ketiga dilakukan dengan analisis korelasi ganda (ry12) koefisien determinasi X1 dan X2 terhadap Y (R2Y12),Uji signifikansi koefisien regresi ganda ( Anova) persamaan garis regresi ganda dengan persamaan garis $\mathrm{Y}=$ $\mathrm{a}+\mathrm{b} 1 \mathrm{x} 1+\mathrm{b} 2 \times 2$ dengan tabel dan pengertiannya. Adapun rumus pengujian hipotetis seperti koefisien korelasi, koefisien determinasi, uji-t, uji-F ( Anova ). Untuk menghitung korelasi ganda, maka harus di hitung terlebih dahulu korelasi sederhananya melalui korelasi product momen dari Pearson.

Adapun analisis validitas, berdasarkan hasil perhitungan dengan memakai software SPSS IBM Advance versi 21 diolah dan dianalisis kemudian disajikan secara lengkap dalam perhitungan Statistik .

Realibilitas pada penelitian ini dilakukan dengan internal consistency dengan teknik belah dua ( Split Half) dengan cara menghitung realibilitas dengan menggunakan rumus Spearman Brown dengan bantuan SPSS IBM Advance Versi 21. Apabila koefisien realibilitas instrument yang dihasilkan lebih besar dari koefisien korelasi maka instrument ini memiliki reliabilitas yang cukup baik maka instrument ini dapat digunakan untuk pengukuran dalam rangka pengumpulan data.

Tabel 3.1

Hipotesis Statistik

\begin{tabular}{|l|c|c|}
\hline 1.Hipotesis I : Ho : & P y1 = & 0 \\
\hline
\end{tabular}




\begin{tabular}{|r|c|c|}
\hline H1 : & P y1 > & 0 \\
\hline 2. Hipotesis II : Ho : & P y2 = & 0 \\
\hline H1 : & P y2> & 0 \\
\hline 3. Hipotesis III : Ho: & P y.12 $=$ & 0 \\
\hline H1: & P y.12> & 0 \\
\hline
\end{tabular}

\section{Hasil Penelitian}

\section{Uji Validitas dan Realibilitas Data}

Untuk keperluan uji instrument penelitian maka dari populasi tersebut disebarkan kuesioner dengan percobaan kepada responden sebanyak 20 orang, kemudian data tersebut diolah dengan menggunakan software Statistical Product and Service Solution ( SPSS ) IBM Advanced Statistic.v 21.

Dibawah ini hasil dari proses SPSS dalam reliabilitas.

1.Variabel Kompensasi (X1).

Tabel. 4.1

\section{Case Processing Summary}

\begin{tabular}{|c|r|r|}
\hline & N & \multicolumn{2}{|c|}{$\%$} \\
\hline Valid & 68 & 100,0 \\
Excluded $^{\mathrm{a}}$ & 0 &, 0 \\
& & \\
& 68 & 100,0 \\
Total & & \\
& & \\
\hline
\end{tabular}

Dari data tabel 4.1 bahwa semua data di proses dengan validasi $100 \%$ valid. Dengan pengujian terhadap 20 responden, masing-masing nilai korelasi 
dibandingkan dengan nilai r-tabel. Dengan taraf signifikan 0.05 di dapat $r$ tabel sebesar 0.444 . Item yang mempunyai korelasi positif dengan skor total serta korelasi yang tinggi, menunjukkan bahwa semua item mempunyai validitas yang tinggi pula.

Jika korelasi antara butir item dengan skor total kurang dari 0,444 maka butir tersebut dinyatakan tidak valid. Oleh karena nilai $r=0,941>$ r-tabel atau 0,941> 0.444 maka dapat di simpulkan bahwa item-item variabel kompensasi reliabel.

2. Variabel Kompensasi (X2).

Tabel 4.2

\section{Reliability Statistics}

\begin{tabular}{|r|r|}
\hline Cronbach's Alpha & $\begin{array}{c}\text { N of } \\
\text { Items }\end{array}$ \\
\hline, 941 & 20 \\
\hline
\end{tabular}

Item-Total Statistics

\begin{tabular}{|c|r|r|r|r|}
\hline & $\begin{array}{c}\text { Scale Mean } \\
\text { if Item } \\
\text { Deleted }\end{array}$ & $\begin{array}{c}\text { Scale } \\
\text { Variance if } \\
\text { Item Deleted }\end{array}$ & $\begin{array}{c}\text { Corrected } \\
\text { Item-Total } \\
\text { Correlation }\end{array}$ & $\begin{array}{c}\text { Cronbach's } \\
\text { Alpha if Item } \\
\text { Deleted }\end{array}$ \\
\hline item_1 & 57,60 & 281,200 &,- 088 &, 946 \\
Item_2 & 58,85 & 247,608 &, 832 &, 935 \\
Item_3 & 59,40 & 240,147 &, 868 &, 934 \\
Item_4 & 58,95 & 248,366 &, 725 &, 936 \\
Item_5 & 59,20 & 241,747 &, 860 &, 934 \\
Item_6 & 59,30 & 243,905 &, 855 &, 934 \\
Item_7 & 59,00 & 240,421 &, 866 &, 934 \\
Item_8 & 59,20 & 243,116 &, 852 &, 934 \\
Item_9 & 59,05 & 244,787 &, 827 &, 935 \\
Item_10 & 59,05 & 242,261 &, 838 &, 934 \\
Item_11 & 58,90 & 257,358 &, 545 &, 940 \\
Item_12 & 59,40 & 256,568 &, 544 &, 940 \\
Item_13 & 58,10 & 270,832 &, 247 &, 943 \\
Item_14 & 57,85 & 276,661 &, 117 &, 944 \\
Item_15 & 58,05 & 269,418 &, 278 &, 943 \\
Item_16 & 58,65 & 247,187 &, 692 &, 937
\end{tabular}




\begin{tabular}{|l|l|l|l|l|} 
Item_17 & 58,40 & 262,989 &, 412 &, 942 \\
Item_18 & 59,05 & 241,524 &, 745 &, 936 \\
Item_19 & 59,00 & 248,421 &, 740 &, 936 \\
Item_20 & 58,15 & 258,134 &, 616 &, 938 \\
\hline
\end{tabular}

Dari hasil data pada tabel 4.2 diatas dengan pengujian terhadap 20 orang didapat nilai Croncbach's Alpha sebesar 0.941 nilai ini jika dibandingkan dengan nilai r-tabel maka dapat kita simpulkan. Dengan taraf signifikan 0.05 dengan $\mathrm{N}=20$ di dapat $\mathrm{r}$-tabel sebesar 0.444 . Item yang mempunyai korelasi positif dengan skor total serta korelasi yang tinggi, menunjukkan bahwa semua item mempunyai validitas yang tinggi pula.

Jika korelasi antara butir item dengan skor total kurang dari 0.444 maka butir tersebut dinyatakan tidak valid. Oleh karena nilai $r=0,941>$ r-tabel atau 0,941>0.444 maka dapat di simpulkan bahwa item - item variabel kompensasi reliabel.

\section{Variabel Situasi Kepemimpinan (X2).}

Tabel 4.3

\section{Reliability Statistics}

\begin{tabular}{|r|r|}
\hline $\begin{array}{c}\text { Cronbach's } \\
\text { Alpha }\end{array}$ & $\begin{array}{c}\text { N of } \\
\text { Items }\end{array}$ \\
\hline, 953 & 18 \\
\hline
\end{tabular}

Item-Total Statistics

\begin{tabular}{|l|r|r|r|r|}
\hline & $\begin{array}{c}\text { Scale Mean } \\
\text { if Item } \\
\text { Deleted }\end{array}$ & $\begin{array}{c}\text { Scale } \\
\text { Variance if } \\
\text { Item Deleted }\end{array}$ & $\begin{array}{c}\text { Corrected } \\
\text { Item-Total } \\
\text { Correlation }\end{array}$ & $\begin{array}{c}\text { Cronbach's } \\
\text { Alpha if Item } \\
\text { Deleted }\end{array}$ \\
\hline Item_1 & 58,9000 & 168,726 &, 173 &, 957 \\
Item_2 & 59,3000 & 153,484 &, 614 &, 952 \\
Item_3 & 58,8500 & 163,187 &, 592 &, 952 \\
Item_4 & 59,1500 & 156,345 &, 708 &, 950 \\
Item_5 & 59,2500 & 150,513 &, 787 &, 948
\end{tabular}




\begin{tabular}{|c|r|r|r|r|} 
Item_6 & 59,0500 & 157,524 &, 613 &, 951 \\
Item_7 & 58,8500 & 161,924 &, 483 &, 953 \\
Item_8 & 58,8500 & 157,082 &, 669 &, 951 \\
Item_9 & 59,4000 & 152,989 &, 846 &, 948 \\
Item_10 & 59,1000 & 152,200 &, 798 &, 948 \\
Item_11 & 59,1500 & 152,976 &, 723 &, 950 \\
Item_12 & 59,5500 & 151,103 &, 875 &, 947 \\
Item_13 & 59,2000 & 156,274 &, 771 &, 949 \\
Item_14 & 59,2000 & 150,484 &, 873 &, 947 \\
Item_15 & 59,7000 & 141,379 &, 840 &, 948 \\
Item_16 & 59,2000 & 148,589 &, 861 &, 947 \\
Item_17 & 59,2000 & 150,484 &, 873 &, 947 \\
Item_18 & 59,1500 & 158,029 &, 681 &, 950 \\
\hline
\end{tabular}

Dari hasil data pada tabel 4.3 diatas dengan pengujian terhadap 20 orang didapat nilai Croncbach's Alpha sebesar 0.953 nilai ini jika dibandingkan dengan nilai r-tabel maka dapat kita simpulkan. Dengan taraf signifikan 0.05 di dapat r-tabel sebesar 0.444. Item yang mempunyai korelasi positif dengan skor total serta korelasi yang tinggi, menunjukkan bahwa semua item mempunyai validitas yang tinggi pula.

Jika korelasi antara butir item dengan skor total kurang dari 0.444 maka butir tersebut dinyatakan tidak valid. Oleh karena nilai $r=0,953>r$-tabel atau 0,953>0.444 maka dapat di simpulkan bahwa item-item variabel situasi kepemimpinan reliabel.

\section{Variabel Iklim Kerja Organisasi (Y).}

Tabel 4.4

\begin{tabular}{|r|r|}
\hline Cronbach's Alpha & $\begin{array}{c}\text { N of } \\
\text { Items }\end{array}$ \\
\hline, 894 & 14 \\
\hline
\end{tabular}

Item-Total Statistics 


\begin{tabular}{|c|r|r|r|r|}
\hline & $\begin{array}{c}\text { Scale Mean if Item } \\
\text { Deleted }\end{array}$ & $\begin{array}{c}\text { Scale Variance if } \\
\text { Item Deleted }\end{array}$ & $\begin{array}{c}\text { Corrected } \\
\text { Item-Total } \\
\text { Correlation }\end{array}$ & $\begin{array}{c}\text { Cronbac } \\
\text { h's } \\
\text { Alpha if } \\
\text { Item } \\
\text { Deleted }\end{array}$ \\
\hline Item_1 & 43,25 & & \\
Item_2 & 43,30 & 78,724 &,- 120 &, 914 \\
Item_3 & 43,40 & 68,537 &, 564 &, 887 \\
Item_4 & 43,35 & 65,200 &, 755 &, 879 \\
Item_5 & 43,75 & 62,345 &, 735 &, 878 \\
Item_6 & 43,30 & 63,776 &, 784 &, 877 \\
Item_7 & 43,55 & 66,011 &, 552 &, 888 \\
Item_8 & 43,50 & 67,734 &, 700 &, 882 \\
Item_9 & 43,45 & 68,474 &, 535 &, 888 \\
Item_10 & 43,55 & 69,629 &, 589 &, 887 \\
Item_11 & 44,10 & 66,787 &, 660 &, 883 \\
Item_12 & 43,60 & 65,989 &, 571 &, 887 \\
Item_13 & 43,45 & 66,042 &, 726 &, 880 \\
Item_14 & 43,50 & 70,050 &, 459 &, 891 \\
\hline
\end{tabular}

Dari hasil data pada tabel 4.4 diatas didapat dengan pengujian terhadap 20 orang nilai Croncbach's Alpha sebesar 0.894 nilai ini jika dibandingkan dengan nilai r-tabel maka dapat kita simpulkan. Dengan taraf signifikan 0.05 di dapat r-tabel sebesar 0.444. Item yang mempunyai korelasi positif dengan skor total serta korelasi yang tinggi, menunjukkan bahwa semua item mempunyai validitas yang tinggi pula.

Jika korelasi antara butir item dengan skor total kurang dari 0.444 maka butir tersebut dinyatakan tidak valid. Oleh karena nilai $r=0,894>r$-tabel atau 0,894> 0.444 maka dapat di simpulkan bahwa item-item variabel terikat iklim kerja organisasi reliabel.

Hasil uji Normalitas Kolmogrof, dasar pengambilan keputusan nya adalah :

- Data berdistribusi Normal jika nilai sig ( signifikansi ) > 0.05

- Data tidak berdistribusi Normal jika nilai sig ( signifikansi ) $<0.05$ 
Tabel 4.5

One-Sample Kolmogorov-Smirnov Test

\begin{tabular}{|c|c|c|}
\hline & & $\begin{array}{c}\text { Unstandardiz } \\
\text { ed Residual }\end{array}$ \\
\hline \multicolumn{2}{|c|}{$\mathrm{N}$} & 68 \\
\hline \multirow{3}{*}{$\begin{array}{c}\text { Normal } \\
\text { Parameters }^{\mathrm{a}, \mathrm{b}}\end{array}$} & Mean &, 0000000 \\
\hline & Std. & 7,93252537 \\
\hline & Deviation & \\
\hline \multirow{3}{*}{$\begin{array}{c}\text { Most Extreme } \\
\text { Differences }\end{array}$} & Absolute & ,061 \\
\hline & Positive &, 061 \\
\hline & Negative &,- 049 \\
\hline \multicolumn{2}{|c|}{ Kolmogorov-Smirnov Z } &, 501 \\
\hline \multicolumn{2}{|c|}{ Asymp. Sig. (2-tailed) } & ,963 \\
\hline
\end{tabular}

a. Test distribution is Normal.

b. Calculated from data.

Berdasarkan uji normalitas dengan Kolmogorof- Smirnof test diperoleh nilai KSZ sebesar 0,501 dan Asymp.sig sebesar 0.963 lebih besar dari 0.05 maka dapat di simpulkan data berdistribusi normal.

Gambar 4.6 menggambarkan bahwa histogram Iklim Kerja Organisasi berdistribusi normal karena bentuk grafik histogram jika di tarik garis lengkung dapat menyentuh area histogram.

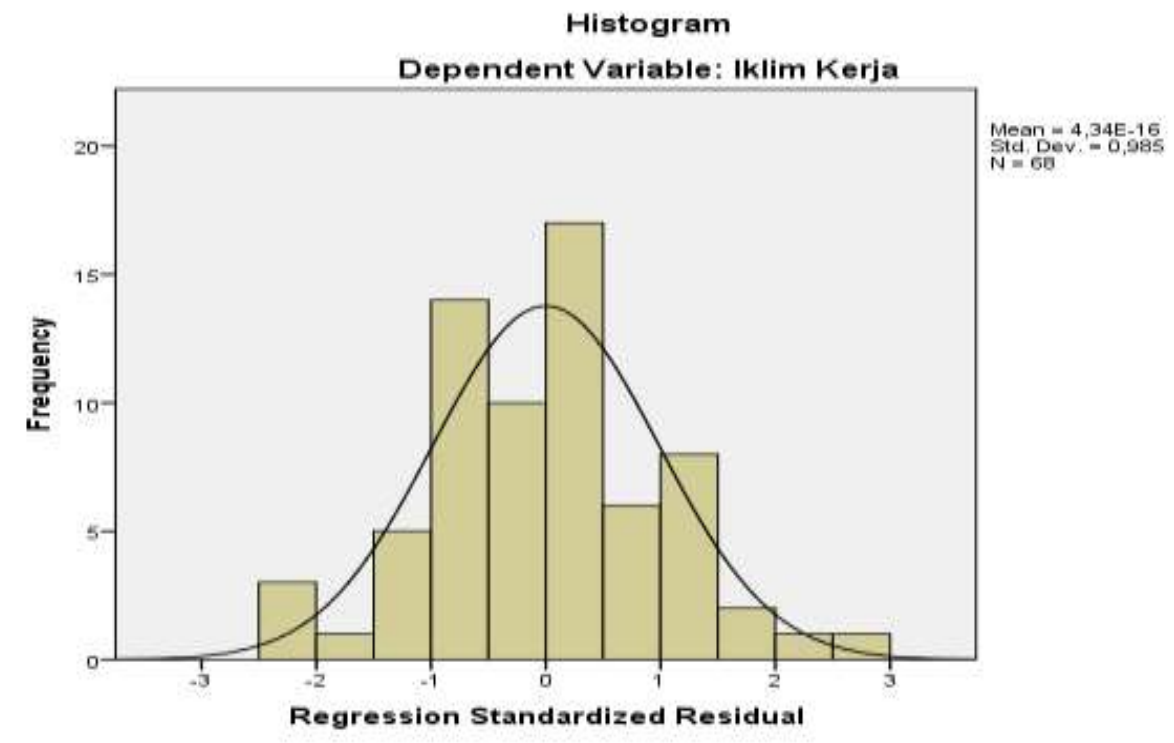

Grafik 4.1 
Meskipun tidak sempurna, berdasarkan histogram diatas, data sudah mendekati bentuk stadar distribusi normal, yaitu sebaran data membentuk bel.

Tabel 4.6

\section{Correlations}

\begin{tabular}{|c|c|c|c|c|}
\hline & & $\begin{array}{c}\text { Iklim } \\
\text { Kerja } \\
\text { Organisasi }\end{array}$ & $\begin{array}{c}\text { Kompens } \\
\text { asi }\end{array}$ & $\begin{array}{c}\text { Situasi } \\
\text { Kepemimpin } \\
\text { an }\end{array}$ \\
\hline \multirow{6}{*}{$\begin{array}{l}\text { Pearson } \\
\text { Correlation }\end{array}$} & Iklim Kerja & 1,000 & ,223 & ,461 \\
\hline & Organisasi & & & \\
\hline & Kompensasi & ,223 & 1,000 & , 470 \\
\hline & Situasi & ,461 & ,470 & 1,000 \\
\hline & Kepemimpinan & & & \\
\hline & Iklim Kerja & & ,034 & ,000 \\
\hline \multirow{4}{*}{ Sig. (1-tailed) } & Organisasi & & & \\
\hline & Kompensasi & 034 & & ,000 \\
\hline & Situasi & ,000 & ,000 & \\
\hline & Kepemimpinan & & & \\
\hline \multirow{5}{*}{$\mathrm{N}$} & Iklim Kerja & 68 & 68 & 68 \\
\hline & Organisasi & & & \\
\hline & Kompensasi & 68 & 68 & 68 \\
\hline & Situasi & 68 & 68 & 68 \\
\hline & Kepemimpinan & & & \\
\hline
\end{tabular}

Bagian Korelasi memberikan informasi mengenai hubungan antara Iklim Kerja dengan Kompensasi dan Situasi Kepemimpinan.

1. Besarnya hubungan antara variabel Iklim Kerja Organisasi dengan Kompensasi adalah 0,223 nilai ini berarti bahwa hubungan kedua variabel tersebut rendah.

Koefisien korelasi positif ( 0,223 ) menunjukkan bahwa hubungan antara variabel Kompensasi dan Iklim Kerja Organisasi searah.

Artinya , jika variabel Kompensasi meningkat, tingkat Iklim Kerja Organisasi juga akan meningkat. 
2. Hubungan antara variabel Kompensasi dan Iklim Kerja Organisasi signifikan .

Jika dilihat dari angka signifikansi ( sig ) 0,034 yang lebih kecil dari 0,05 didasarkan pada ketentuan, jika angka signifikansi $<0,05$, hubungan antara kedua variabel tersebut signifikan.

Sementara tabel-t dengan taraf signifikansi 0,05 dan jumlah data 68 menunjukkan nilai 1.668. Karena t-hitung lebih kecil dari nilai t tabel, maka Ho diterima dan $\mathrm{H} 1$ ditolak.

Ini berarti bahwa Kompensasi guru lemah pengaruhnya terhap Iklim Kerja Organisasi.

3. Besarnya hubungan antara variabel Situasi Kepemimpinan dengan Iklim Kerja Organisasi adalah 0,461 . Nilai ini berarti bahwa hubungan kedua variabel tersebut hubungan Sedang. Koefisien korelasi positif ( 0,000), menunjukkan bahwa hubungan antara variabel Iklim Kerja Organisasi dan Situasi Kepemimpinan searah.

Artinya, Jika variabel Situasi Kepemimpinan membaik maka Iklim Kerja Organisasi juga akan membaik.

4. Hubungan antara variabel Situasi Kepemimpinan dan Iklim Kerja Organisasi jika dilihat dari angka signifikan ( Sig ) sebesar ( 0,00 ) yang lebih kecil dari 0,05 didasarkan pada ketentuan , jika angka signifikansi < 0,05 hubungan antara kedua variabel tersebut signifikan.

Tabel 4.7

Hasil Analisis Regresi Linear Berganda

Coefficients $^{\mathbf{a}}$ 


\begin{tabular}{|c|c|c|c|c|c|c|c|c|}
\hline & \multirow[t]{2}{*}{ Model } & \multicolumn{2}{|c|}{$\begin{array}{l}\text { Unstandardized } \\
\text { Coefficients }\end{array}$} & \multirow{2}{*}{$\begin{array}{c}\begin{array}{c}\text { Standardi } \\
\text { zed } \\
\text { Coefficie } \\
\text { nts }\end{array} \\
\text { Beta }\end{array}$} & \multirow[t]{2}{*}{$\mathrm{t}$} & \multirow[t]{2}{*}{ Sig. } & \multicolumn{2}{|c|}{$\begin{array}{c}\text { Collinearity } \\
\text { Statistics }\end{array}$} \\
\hline & & B & $\begin{array}{l}\text { Std. } \\
\text { Error }\end{array}$ & & & & $\begin{array}{c}\text { Tolera } \\
\text { nce }\end{array}$ & VIF \\
\hline & (Constant) & 26,858 & 6,329 & & 4,244 & ,000 & & \\
\hline & Kompensasi & ,006 & ,084 & ,009 & ,070 & ,945 &, 780 & 1,283 \\
\hline 1 & $\begin{array}{c}\text { Situasi } \\
\text { Kepemimpi } \\
\text { nan }\end{array}$ &, 347 & ,095 & ,457 & 3,668 & ,000 &, 780 & 1,283 \\
\hline
\end{tabular}

a. Dependent Variable: Iklim Kerja Organisasi

Bila nilai - nilai tersebut dimasukkan ke dalam persamaan regresi linear berganda, maka :

$\begin{array}{llll}\mathrm{Y}= & 26,858+ & 0,006 \mathrm{X} 1 & 0,347 \mathrm{X} 2 \\ \mathrm{SE} & =6,329 & 0,084 & 0,095 \\ \text { Thitung }= & 4,244 & 0,070 & 3,668 \\ \mathrm{SCb}= & 0,009 & 0,095 \\ \mathrm{Sig}= & 0,000 & 0,945 & 0,000\end{array}$

Keterangan :

Y : Iklim Kerja Organisasi

X1 : Kompensasi

X2 : Situasi Kepemimpinan

SE : Standar Error

$\mathrm{SCb}:$ Standarized Coefficient (Beta)

Sig : Tingkat signifikan

Persamaan ini mengandung pengertian sebagai berikut :

5. Setiap Variabel X1 naik satu satuan dengan asumsi X2 tetap maka mengakibatkan nilai Y naik sebesar 0,006. 
6. Setiap Variabel X2 naik satu satuan dengan asumsi X1 tetap maka mengakibatkan nilai Y naik sebesar 0,347

7. Secara bersama-sama jika $X 1$ dan $X 2$ naik sebesar satu satuan secara bersama-sama mengakibatkan nilai Y naik sebesar 0,353.

Persamaan regresi linear diatas digunakan untuk memprediksi nilai dari variabel Iklim Kerja Organisasi guru apabila nilai Kompensasi, dan Situasi Kepemimpinan mengalami kenaikan atau penurunan.

\section{Analisis Hipotesis 1}

Hipotesis pertama berbunyi "terdapat hubungan positif signifikan Kompensasi dengan Iklim Kerja Organisasi “.

Berdasarkan data pada tabel 4.7 Diketahui koefisien regresi $(\mathrm{b} 1)=0,006$ dengan standar error $(\mathrm{SE})=0,084$. Dengan membagi bilangan b1 dengan SE maka di hasilkan t-hitung sebesar 0,071. Sementara tabel-t dengan taraf signifikansi 0,05 dan jumlah data 68 menunjukkan nilai 1.668. Karena t-hitung lebih kecil dari nilai t tabel, maka Ho diterima dan H1 ditolak.

Ini berarti bahwa Kompensasi guru lemah pengaruhnya terhap Iklim Kerja Organisasi.

\section{Analisis Hipotesis 2}

Hipotesis Kedua berbunyi “Terdapat hubungan positif signifikan Situasi Kepemimpinan dengan Iklim Kerja Organisasi “.

Berdasarkan data dalam tabel 4.7, diketahui koefisien regresi (b2) $=0,347$ dengan standar error $(\mathrm{SE})=0,095$ dengan membagi bilangan b2 dengan SE maka dihasilkan nilai t hitung sebesar 3,65. Sementara pada tabel t dengan taraf signifikansi 0,05 dan jumlah data 68 menunjukkan nilai 1,668. Karena nilai t hitung lebih besar dari nilai tabel, maka Ho di tolak dan $\mathrm{H} 2$ diterima. 
Hal ini membuktikan bahwa hipotesis kedua yang diajukan dapat diterima , yaitu secara parsial terdapat pengaruh positif signifikan Situasi Kepemimpinan dengan iklim kerja organisasi.

Dengan interprestasi bahwa koefisien regresi Situasi Kepemimpinan mempunyai pengaruh yang positif, yang dapat meningkatkan Iklim Kerja Organisasi sehingga keluar masuknya guru bisa dihilangkan jika kepemimpinan di tingkatkan.

\section{Analisis Hipotesis 3}

Hipotesis ketiga bertujuan untuk mengetahui pengaruh bersama Kompensasi dan Situasi Kepemimpinan terhadap Iklim Kerja Organisasi. Hipotesis Ketiga berbunyai : "Terdapat hubungan bersama positif signifikan Kompensasi dan Situasi Kepemimpinan dengan Iklim Kerja Organisasi “.

Untuk menguji hipotesis ketiga digunakan analisis determinasi berganda serta analisis regresi berganda. Hasil analisis di tunjukkan dalam tabel 4.8

Tabel 4.8

Hasil Analisis Determinasi Berganda

Model Summary

\begin{tabular}{|l|r|r|r|r|}
\hline $\begin{array}{l}\text { Mode } \\
1\end{array}$ & R & R Square & $\begin{array}{c}\text { Adjusted R } \\
\text { Square }\end{array}$ & $\begin{array}{l}\text { Std. Error of } \\
\text { the Estimate }\end{array}$ \\
\hline 1 &, $461^{\mathrm{a}}$ &, 213 &, 189 & 8,030 \\
\hline
\end{tabular}

a. Predictors: (Constant), Situasi Kepemimpinan,

Kompensasi

Dari tabel ringkasan model menunjukkan besarnya koefisien determinasi yang berfungsi untuk mengetahui besarnya variabilitas variabel tergantung Iklim Kerja Organisasi yang dapat diterangkan dengan menggunakan variabel bebas Kompensasi (X1) dan Situasi Kepemimpinan(X2). 
Koefisien determinasi juga digunakan untuk menghitung besarnya peranan atau pengaruh variabel bebas terhadap varibel tergantung.

Koefisien determinasi dihitung dengan cara mengalikan $\mathrm{r}^{2}$ dengan $100 \%$ $\left(\mathrm{r}^{2} \times 100 \%\right)$. Nilai $\mathrm{r}$ Sguare dalam tabel diatas adalah 0,213 , angka $\mathrm{R}$ Sguare disebut juga koefisien determinasi. Besarnya angka koefisien determinasi adalah 0,213 atau sama dengan 21,30\%. Angka tersebut berarti bahwa sebesar 21,3\% tingkat Iklim Kerja Organisasi (Y) yang baik dapat dijelaskan dengan menggunakan variabel Kompensasi(X) dan Situasi Kepemimpinan(X2) sisanya dipengaruhi oleh faktor lainnya.

Tabel 4.9

Matrik Korelasi antar Dimensi dalam Variabel

\begin{tabular}{|c|c|c|c|c|}
\hline \multicolumn{5}{|c|}{ Correlations } \\
\hline & & $\begin{array}{l}\text { Iklim Kerja } \\
\text { Organisasi }\end{array}$ & Kompensasi & $\begin{array}{c}\text { Situasi } \\
\text { Kepemimpin } \\
\text { an }\end{array}$ \\
\hline \multirow{8}{*}{$\begin{array}{l}\text { Iklim } \\
\text { Kerja } \\
\text { Organisasi }\end{array}$} & Pearson Correlation & 1 &, 223 &, $461^{* *}$ \\
\hline & Sig. (2-tailed) & &, 067 &, 000 \\
\hline & Sum of Squares and & 5324,750 & 1764,750 & 3239,250 \\
\hline & Cross-products & & & \\
\hline & Covariance & 79,474 & 26,340 & 48,347 \\
\hline & $\mathrm{N}$ & 68 & 68 & 68 \\
\hline & Pearson Correlation & 223 & 1 &, $470^{* *}$ \\
\hline & Sig. (2-tailed) &, 067 & &, 000 \\
\hline \multirow{6}{*}{$\begin{array}{l}\text { Kompensa } \\
\text { si }\end{array}$} & Sum of Squares and & 1764,750 & 11724,632 & 4892,603 \\
\hline & Cross-products & & & \\
\hline & Covariance & 26,340 & 174,995 & 73,024 \\
\hline & $\mathrm{N}$ & 68 & 68 & 68 \\
\hline & Pearson Correlation &, $461^{* *}$ &, $470^{* *}$ & 1 \\
\hline & Sig. (2-tailed) &, 000 &, 000 & \\
\hline \multirow{4}{*}{$\begin{array}{l}\text { Situasi } \\
\text { Kepemim } \\
\text { pinan }\end{array}$} & Sum of Squares and & 3239,250 & 4892,603 & 9261,691 \\
\hline & Cross-products & & & \\
\hline & Covariance & 48,347 & 73,024 & 138,234 \\
\hline & $\mathrm{N}$ & 68 & 68 & 68 \\
\hline
\end{tabular}

**. Correlation is significant at the 0.01 level (2-tailed). 
Berdasarkan data dalam tabel 4.9, didapat nilai korelasi yang terjadi antar demensi dalam variabel sebagai berikut :

1. Dimensi Kompensasi dengan Iklim Kerja sebesar 0,461

2. Dimensi Situasi Kepemimpinan dengan Iklim Kerja Organisasi sebesar 0,470.Berdasarkan data di atas dapat diinterprestasikan bahwa nilai korelasi antara dimensi dalam variabel yang paling kuat adalah terjadi pada dimensi Situasi Kepemimpinan(X2)

Tabel 4.10

Hasil Uji Signifikansi Simultan (Uji F)

\begin{tabular}{|c|c|c|c|c|c|c|}
\hline \multicolumn{7}{|c|}{ ANOVA $^{\mathrm{a}}$} \\
\hline & & $\begin{array}{c}\text { Sum of } \\
\text { Squares }\end{array}$ & Df & $\begin{array}{l}\text { Mean } \\
\text { Square }\end{array}$ & $\mathrm{F}$ & Sig. \\
\hline \multirow{3}{*}{1} & Regression & 1133,232 & 2 & \multirow{3}{*}{$\begin{array}{r}566,616 \\
64,485\end{array}$} & \multirow[t]{3}{*}{8,787} & \multirow[t]{3}{*}{, $000^{b}$} \\
\hline & Residual & 4191,518 & 65 & & & \\
\hline & Total & 5324,750 & 67 & & & \\
\hline
\end{tabular}

a. Dependent Variable: Iklim Kerja Organisasi

b. Predictors: (Constant), Situasi Kepemimpinan, Kompensasi

Hasil uji Signifikansi Simultan digunakan untuk mengetahui apakah koefisien korelasi itu dapat di genaralisasikan maka dilakukan uji signifikansi. Hasil Uji signifikansi ditunjukkan dalam tabel diatas.

Hasil uji signifikansi simultan diperoleh nilai $\mathrm{F}$ hitung sebesar 8,787 harga ini kemudian di konsultasukan dengan tabel F, dengan taraf signifikansi 0,05 dan jumlah data 68, hasil diperoleh untuk F tabel sebesar 3,982

Karena nilai $\mathrm{F}$ hitung lebih besar dari nilai $\mathrm{F}$ tabel 8,787>3,982, maka Ho ditolak dan H1 diterima, yaitu : “terdapat pengaruh bersama positif signifikan Kompensasi (X1) dan Situasi Kepemimpinan (X2) dengan Iklim Kerja Organisasi (Y). 


\section{Kesimpulan}

Berdasarkan hasil pengujian hipotesis dan korelasi dimensi antara variabel maka kesimpulan penelitian ini adalah sebagai berikut :

1. Secara parsial terdapat pengaruh positif signifikan Kompensasi dengan Iklim Kerja Organisasi. Korelasi sangat kuat terdapat pada jenis kompensasi yang diberikan.

2. Secara parsial terdapat pengaruh yang positif signifikan Situasi Kepemimpinan dengan Iklim Kerja Organisasi. Korelasi sangat Kuat adalah terdapat pada dimensi Hubungan pemimpin dengan anggota.

3. Secara SimultanTerdapat pengaruh bersama positif signifikan Kompensasi dan Situasi Kepemimpinan dengan Iklim Kerja Organisasi.

Dengan demikian dimensi gaji yang diterima, jenis kompensasi yang diberikan, hubungan Kepala sekolah dengan guru merupakan dimensi-dimensi yang secara nyata turut menentukan Iklim Kerja Organisasi.

\section{DAFTAR PUSTAKA}

Albertus Heriyanto (2011) Manajemen Sumber Daya Manusia (ed.Revisi). Jakarta , Prestasi Pusaka.

Arikunto (2007) Manajemen Penelitian, Jakarta, Bhineka Cipta

Candiasa, I Made, Statistik Multivariat Disertai Aplikasi dengan SPSS, Singaraja : Unit Penerbitan IKIP Negeri Singaraja, 2003 
Candiasa, I Made, Statistik Multivariat Disertai Aplikasi dengan SPSS, Singaraja : Unit Penerbitan IKIP Negeri Singaraja, 2003

Dessler Gary (2009) Manajemen Sumber Daya Manusia (10 th ed). Jakarta , PT.Indeks.

Erman (2003) Evaluasi Pelajaran Matematika (Untuk Guru dan Mahasiswa) Bandung, JICA

Harianja, Marihot (2002), Manajemen Sumber Daya Manusia, Pengadaan, Pengembangan, Pengkompensasian dan Peningkatan Produktivitas Karyawan, Jakarta, PT. Grasindo

Hasibuan, H. Melayu (2006) Manajemen Sumber Daya Manusia (ed .Revisi). Jakarta, PT. Bumi Aksara

Handoko, T.Hari (1987) Manajemen Personalia dan Sumber Daya Manusia Yokyakarta, BPFE -Yokyakarta

Jonathan Sarwono (2012) IBM SPSS Advance Statistic, Yokyakarta, Penerbit ANDI

Mangkunegara, Anwar Prabu (2011), Manajemen Sumber Daya Manusia Perusahaan, Bandung, PT. Remaja Rosda Karya.

Sinambela, Lijan Poltak (2012) Kenerja Pegawai Teori Pengukuran dan Implikasi. Yokyakarta, PT. Graha Ilmu.

Sugiyono (2013) Metode Penelitian Pendidikan (Pendekatan Kuantitatif) Bandung, PT. Alfabeta

Sugiyono (2010) Metode Penelitian Bisnis (Pendekatan Kuantitatif ) Bandung , PT. Alfabeta 
Sugiyono (2013) Metode Penelitian Pendidikan (Pendekatan Kuantitatif) Bandung, PT. Alfabeta

Sukma dinata, Nana saodih (2007) Metode Penelitian Pendidikan . Bandung, PT. Remaja Rosdakarya

Trihendradi, C (2007 Memecahkan Kasus Statistik : Deskriptif, parametrik dan NonParametrik dengan SPSS 12. Penerbit ANDI. Yokyakarta

Widianto Joko (2012) SPSS For Windows Surakarta.Badan Penerbit - FKIP Universitas Muhammadiah Surakarta. 